\title{
TPHA and RPL tests for yaws antibodies
}

\author{
A. FISCHMAN, A. D. BREE, AND R. A. LYNCH \\ Treponema Reference Laboratory, Auckland Hospital, Park Road, Auckland, New Zealand
}

Numerous serological studies have been done on people living as natives in yaws endemic territories (Guthe, Ridet, Vorst, D'Costa, and Grab, 1972; Garner, Backhouse, Daskalopoulos, and Walsh, 1972) to establish epidemiological patterns or evaluate mass treatment. The local population of New Zealand has no yaws; however, there is a large influx of immigrant Pacific Islanders with yaws antibodies.

In a previous study (Fischman and Mundt, 1971) the value of two non-microscopical tests, the Treponema pallidum haemagglutination (TPHA) and the slide Reiter protein latex (RPL) test, in confirming yaws antibodies in sera reactive with reagin screening tests, has been shown. In the present study a different group of Pacific Islanders have been screened with these treponemal tests, irrespective of reagin test results, to see if they are preferable to the reagin tests in dianostic screening or epidemiological studies.

Guthe and others (1972) have pointed out the growing importance of treponemal tests (FTA or TPI or both) as compared with reagin tests. We have examined possible advantages of the TPHA and RPL tests as compared with the FTA test, and discuss these tests and the TPI test in relation to the differential diagnosis of yaws and syphilis.

\section{Material and methods}

TPHA, RPL, Wassermann, and VDRL tests have been performed on 460 sera of immigrants from Pacific Islands

Received for publication January 30, 1974 who are now residing in New Zealand. Most were from women in the 19- to 32-year age group. The TPHA test has also been performed on an additional 750 sera. 320 of the latter as well as the 460 specimens were also tested with the FTA-ABS test.

The methods have been described previously (Fischman and Mundt, 1971), except that the TPHA was performed as a manual quantitative micromethod based on the automated technique of Cox, Logan, and Norins (1969) and described in the instructions of Fuji Zoki Co. accompanying the reagents. The first dilution was $1: 40$, it having been found that confirmation of positive tests at this dilution by the FTA-ABS test was of the same order as in those positive at a dilution of $1: 80$.

\section{Results}

The TPHA test was reactive in 50.3 per cent. of the 460 sera, and the RPL in 53.4 per cent. The WR was reactive in 25 per cent., the VDRL in 19.2 per cent. Even the combined reagin test reactivity of 31.7 per cent. (with at least one reagin test positive) was much below that of the treponemal tests.

Agreement between TPHA and RPL tests, both being either positive or negative, was 80 per cent., a small percentage of sera reacting with one of the tests only. While reagin-positive sera reacted approximately twice as frequently in the treponemal tests, as many as 28.3 per cent. of reagin-negative sera reacted in both the TPHA and RPL tests (Table I).

The TPHA showed reasonably good correlation with a confirmatory FTA-ABS. The sensitivity of the TPHA was slightly higher than that of the FTA-ABS test. In 780 sera tested with both these tests, 404

TABLE I Relation of $T P H A, R P L$, and reagin test reactivity

\begin{tabular}{|c|c|c|c|c|c|c|}
\hline \multirow[b]{2}{*}{ Tests } & \multicolumn{2}{|c|}{ Reagin +} & \multicolumn{2}{|c|}{ Reagin- } & \multicolumn{2}{|c|}{ All sera } \\
\hline & No. & Per cent. & No. & Per cent. & No. & Per cent. \\
\hline $\begin{array}{l}\text { TPHA + RPL + } \\
\text { TPHA - RPL - } \\
\text { TPHA + RPL - } \\
\text { TPHA - RPL + }\end{array}$ & $\begin{array}{r}103 \\
13 \\
16 \\
14\end{array}$ & $\begin{array}{r}70.6 \\
8.9 \\
10.9 \\
9.6\end{array}$ & $\begin{array}{r}89 \\
161 \\
24 \\
40\end{array}$ & $\begin{array}{r}28 \cdot 3 \\
51 \cdot 4 \\
7 \cdot 6 \\
12 \cdot 7\end{array}$ & $\begin{array}{r}192 \\
174 \\
40 \\
54\end{array}$ & $\begin{array}{r}41 \cdot 7 \\
37 \cdot 9 \\
8 \cdot 7 \\
11 \cdot 7\end{array}$ \\
\hline Total & 146 & $100 \cdot 0$ & 314 & $100 \cdot 0$ & 460 & $100 \cdot 0$ \\
\hline
\end{tabular}


sera reacted with one or both. In these 404 sera both tests were positive in 88.1 per cent., the TPHA reacting in 96.5 per cent. (390) and the FTA-ABS in 91.5 per cent. (370). The TPHA alone was positive in 34 sera ( 8.4 per cent.), the FTA-ABS alone in 14 ( 3.4 per cent.).

Confirmation of the RPL test by the FTA-ABS test was somewhat less frequent. In the main series of 460 sera, 273 reacted in either both or one of these tests. In these 273 sera both tests were positive in 76.2 per cent., the RPL showing a sensitivity of 90.2 per cent. and the FTA-ABS 86.1 per cent. In 14 per cent. the sera gave reactive RPL but negative FTA-ABS tests, while 9.9 per cent. of sera reacted only in the FTA-ABS test.

It is of interest that there were only eleven (5.7 per cent.) sera with negative FTA-ABS tests among those which were positive in both TPHA and RPL tests. When the reactive RPL tests were unsupported by the TPHA results, 59.2 per cent. of these (32) had a negative FTA-ABS (Table II). This constitutes possible false positive RPL tests in approximately 7 per cent. of the 460 sera.

TABLE II FT $A$ - $A B S$ reactivity of sera shown in Table I which have positive TPHA and/or RPL

\begin{tabular}{|c|c|c|c|c|}
\hline \multirow[b]{2}{*}{ Tests } & \multicolumn{2}{|c|}{$F T A+$} & \multicolumn{2}{|c|}{$F T A-$} \\
\hline & No. & Per cent. & No. & Per cent. \\
\hline $\begin{array}{l}\text { RPL + TPHA + } \\
\text { RPL - TPHA + } \\
\text { RPL + TPHA - }\end{array}$ & $\begin{array}{r}181 \\
34 \\
22\end{array}$ & $\begin{array}{l}94 \cdot 3 \\
85 \cdot 0 \\
40 \cdot 8\end{array}$ & $\begin{array}{r}11 \\
6 \\
32\end{array}$ & $\begin{array}{r}5 \cdot 7 \\
15 \cdot 0 \\
59 \cdot 2\end{array}$ \\
\hline
\end{tabular}

The majority of TPHA titres in 600 Islanders were relatively low, 95 per cent. not exceeding $1: 320$, and only three $(0.5$ per cent.) exceeding $1: 1,000$ (Table III).

TABLE III Reciprocal TPHA titres of 600 sera

\begin{tabular}{lcccccr}
\hline Titres & 40 & 80 & $160-320$ & 640 & 1,280 & $>1,280$ \\
Percentage & $4 \cdot 1$ & 46.6 & $44 \cdot 3$ & 4.5 & 0.5 & 0 \\
\hline
\end{tabular}

\section{Discussion}

Reagin tests appear to be inferior as screening tests for yaws antibodies in this group of Pacific Islanders with no active yaws. They have shown lower sensitivity than two non-microscopical treponemal tests (Fischman and Mundt, 1971). The difference is more marked when both reagin-reactive and non-reactive sera are tested. As no children's sera, and only a few sera in an older age group were available, it was not possible to investigate whether reagin reactivity is increasing with age, as demonstrated in some endemic areas (Guthe and others, 1972).
The TPHA and RPL tests are slightly more sensitive than the FTA-ABS. A reactive TPHA test, especially if supported by a reactive RPL, is usually confirmed by the FTA-ABS. A reactive RPL test accompanied by a negative TPHA has a low specificity as measured by the FTA-ABS.

It does not seem justified to state that a serum giving a positive TPHA test and negative FTA-ABS test does not contain yaws antibodies. Further testing with the TPI test may not solve this problem. Garner and others (1972) confirmed our previous finding that the TPHA is more sensitive than the FTA-ABS. They also found the TPHA more sensitive than the TPI, but stated that neither could replace the TPI as a test for yaws. However, as the FTA-ABS is more sensitive than the TPI in most stages of treated and untreated syphilis, this conflict may make interpretation difficult (Wilkinson, 1972). This difficulty is likely to apply to yaws also, especially in a group from a yaws endemic territory, with no available history or clinical signs. Luger and Spendlingwimmer (1973), found the TPHA test more sensitive than the FTA-ABS in latent syphilis. According to Johnston (1972), the majority of TPHAreactive, TPI-negative sera are from patients with a previous history of treated or untreated syphilis or yaws; the TPHA was considered slightly more sensitive than the TPI in late syphilis. Lesiński and Krach-Kaczmarczyk (1973) drew similar conclusions, considering the TPHA valuable and confirmatory in FTA-positive, TPI-negative sera. Some of these discrepancies may be due to a reactive TPHA persisting longer after treatment than other tests.

In view of the above, and because of greater simplicity and easier availability, it appears justifiable to use the non-microscopical treponemal tests in the detection of yaws antibodies, without recourse to the microscopical tests, especially for epidemiological purposes. If the microscopical tests are used for diagnostic confirmation, one could classify the sera as containing definite yaws antibodies, if confirmed by FTA or TPI, and probable yaws antibodies if not confirmed. To use a negative TPI as an exclusion test is questionable. While the RPL is the simplest treponemal test, it needs confirmation. The TPHA may be used as a single test, or combined with the RPL or FTA-ABS.

It has been reported previously (Fischman and Skorepova, 1973) that in Pacific Islanders residing in New Zealand the TPHA titre rarely exceeds $1: 1,000$, while this happens in 17 per cent. of European syphilitic sera. This pattern continued in the present larger series. The only clinically confirmed syphilis reported in an Islander (Wilson and Mauger, 1973) had a TPHA titre exceeding $1: 1,000$ (Fischman, 
unpublished) and a VDRL of $1: 8$. Thus, if a high titre TPHA is found, syphilis may be suspected. This limited differential diagnostic pointer between yaws and syphilis may not apply in a population with active yaws. Johnston (1972) found more high TPHA titres in Congolese pygmies presumed to have untreated yaws. The great discrepancy between reagin and treponemal test reactivity in the present studyconsistently weak or negative reagin reactions-is also likely to be present in a group with residual yaws antibodies only, and reinforces the suggestion made previously (Fischman and Mundt, 1971) that the pattern of test results can help to exclude syphilis in this Pacific Island group.

\section{Summary}

In a group of 460 Pacific Islanders from yaws endemic territories who emigrated to New Zealand, treponemal tests were reactive twice as frequently as reagin tests. The TPHA and RPL tests were reactive in 50.3 and 53.4 per cent. respectively, as compared with 25 per cent. for the Wassermann reaction and 19.2 per cent. for the VDRL.

The two non-microscopical treponemal tests, the TPHA and RPL, may be used to detect yaws antibodies, without recourse to the more elaborate FTA-ABS or TPI.

Using the FTA-ABS for further confirmation, good agreement was shown between the TPHA and FTA-ABS, with the TPHA showing somewhat higher sensitivity, 8.7 per cent. of TPHA-reactive sera giving negative FTA-ABS tests. These sera were considered as having probable yaws antibodies. The literature supporting the view that, in a group with residual yaws antibodies, the TPHA may be more sensitive in their detection than either the FTA-ABS or TPI, the latter being of questionable value as an exclusion test, has been discussed.

The RPL is a simple test, but has limitations as a screening test because its specificity is lower than that of other treponemal tests, and needs confirmation by the TPHA, FTA-ABS, or TPI.

TPHA titres have some limited value in detecting the apparently rare cases of syphilis in the immigrant Islanders.

\section{References}

Cox, P. M., Logan, L. C., and Norins, L. C. (1969) Appl. Microbiol., 18, 485
Fischman, A., and Mundt, H. (1971) Brit. F. vener. Dis., 47, 91

and Skorepova, G. (1973) Trans. roy. Soc. trop. Med. Hyg., 67, 421

Garner, M. F., Backhouse, J. L., Daskalopoulos, G., and WALSH, J. L. (1972) Brit. F. vener. Dis., 48, 479

Guthe, T., RIDET, J., Vorst, F., D'Costa, J., and GraB, B. (1972) Bull. Wld Hlth Org., 46, 1

Johnston, N. A. (1972) Brit. F. vener. Dis., 48, 474

LESIŃSKI, J., and KRACH-KACZMARCZYK, J. (1973) WHO/ VDT $/$ Res $/ 73.298$

Luger, A., and SPendlingwimmer, I. (1973) Brit. $\mathcal{F}$. vener. Dis., 49, 181

Wilkinson, A. E. (1972) Brit. med. F., 2, 573

WIISON, J., and MAUGER, D. G. (1973) N.Z. med. f., 77, 384

Recherche des anticorps pianiques par le TPHA et le RPL

\section{SOMMAIRE}

Dans un groupe de $\mathbf{4 6 0}$ habitants des îles du Pacifique où le pian est endémique et qui émigrèrent en Nouvelle Zélande, la sérologie tréponémique fut positive deux fois plus souvent que les tests de réagine. Respectivement, le TPHA et le RPL furent positifs dans 50,3 et dans 53,4 pour cent des cas contre 25 pour cent pour la réaction de Wassermann et 19,2 pour cent pour le VDRL.

Le TPHA et le RPL, tests ne faisant pas intervenir des tréponèmes figurés, peuvent être utilisés pour mettre en évidence les anticorps pianiques sans avoir à recourir au FTA-ABS ou au TPI, plus compliqués.

Employant le FTA-ABS, pour confirmation ultérieure, on constata un bon accord entre le TPHA et le FTA-ABS, le TPHA montrant une sensibilité quelque peu supérieure: 8,7 pour cent des sérums positifs au TPHA étaient négatifs au FTA-ABS. On considère que ces sérums contenaient probablement des anticorps pianiques. On discute la littérature en faveur du point de vue que, dans un groupe présentant des anticorps pianiques résiduels, le TPHA peut être plus sensible pour les détecter que ou le FTA-ABS ou le TPI, ce dernier apparaissant de valeur discutable comme épreuve d'exclusion.

Le RPL est un test simple mais qui a ses limites en tant qu'épreu ve de dépistage, du fait de sa moindre spécificité que celle des autres tests tréponémiques et de la nécessité de le confirmer par le TPHA, le FTA-ABS ou le TPI.

Les titres TPHA ont une valeur quelque peu limitée pour détecter les cas apparemment rares de syphylis chez les émigrants insulaires. 